\title{
変動応カ下における若材齢高強度コンクリート のクリープ評価に関する研究
}

\author{
小澤満津雄 $1 \cdot$ 細井陽介 ${ }^{2} \cdot$ 森本博昭 $^{3}$ \\ '正会員 工修 岐阜大学助手 工学部社会基盤工学科 （テ501-1193 岐阜県岐阜市柳戸1-1） \\ mitsu@cc.gifu-u.ac.jp \\ $2^{2}$ 豊橋市役所 $\quad(\bar{T} 440-8501$ 愛知県豊橋市今橋町 1 番地 $)$ \\ ${ }^{3}$ 正会員 工博 岐阜大学教授 工学部社会基盤工学科 （テ501-1193 岐阜県岐阜市柳戸1-1）
}

\begin{abstract}
コンクリートの温度応力解析においてクリープは, 履歴理論による重ね合せ理論（以下, 重ね合せ理 論）によって評価されるのが一般的である．温度応力パターンのように圧縮応力から引張応力に反転する 場合, 従来の重ね合せ理論では, 圧縮応力の減少(除荷)を引張応力の載荷と考えるのに対し, 本研究（修 正重ね合せ理論）では，圧縮忘力の除荷ととらえ，クリープを推定する．その際，圧縮クリープ試験から 求められたクリープ回復率を用いる. また, 除荷の影響を考慮するため, 除荷応力の大きさに応じて, 先 行載荷応力を減じる手法を提案する. 三,三の推定例を示して, 本手法により, 圧縮応力から引張応力に反 転する場合のクリープを精度よく推定できることを明らかにする.
\end{abstract}

Key Words: high-strength concrete, creep, superposition, early ages, recovery creep

\section{1. はじめに}

コンクリートのクリープは，コンクリート構造物に作 用する持続応力により，変形が増大する現象であり，時 間依存変形問題などに対し，無視することができない. これまでにコンクリートのクリープに関する研究につい て, 数多くの研究がなされている. しかし，若材㱓期を 対象としたコンクリートのクリープ特性については，十 分な研究成果が得られているとは言い難い. 特に, 若材 齢期においては，温度応力および自己収縮応力などのい わゆる初期応力が発生し, その発生履歴も大きく変化す る. 変動応力下におけるクリープの推定については, 履 歴理論 にによる重ね合せ理論(以下, 重ね合せ理論)が一 般的であるが，その適用性について，十分検証されてい ないのが現状である. 一方, 近年, 使用量が増加してい る高強度コンクリートでは, 大きな自己収縮が発生する ため, 温度応力とともに自己収縮応力の解明が急務とな っている. しかし, 高強度コンクリートのクリープ特性 についての基礎資料の蓄積は十分ではない.このような 現状を踏まえて, 本研究では(1)重ね合せ理論の適用性の 問題点を指摘し，除荷過程における応力の取り扱いを考 慮した修正重ね合せ理論を提案する，次に，修正重ね合 せ理論の適用性を検証することおよび，基礎資料の蓄積 の少ない高強度コンクリートの若材齢期のクリープ特性
を明らかにし，実験より得られたクリープ関数をもとに， 若材齢期の変動応力下におけるクリープ評価法について 検討を行う。また，普通コンクリートについても，参考 文献より引用した実験データについて, 修正重ね合せ理 論の適用性の検証を行った. 本研究では特に, 温度応力 を模擬した応力パターンについて, 圧縮応力の載荷除荷 および反転に伴うクリープの挙動の推定法を検討した. 従来の重ね合せ理論では, 圧縮応力の減少(除荷)を引張 応力の載荷と考えるのに対し, 本研究では, 圧縮応力の 除荷ととらえ，クリープを推定する．その際，圧縮クリ 一プ試験から求められたクリープ回復率を用いる. また, 除荷の影響を考慮するため, 除荷応力の大きさに応じて, 先行載荷応力を减じる手法を提案する. 三,三の推定例 を示して, 本手法により, 圧縮応力から引張応力に反転 する場合のクリープを精度よく推定できることを明らか にする.

\section{2. 変動応カ下における若材龄コンクリートのク リープ評価に関する既往の研究}

ここでは, 変動応力下における若材齢コンクリート のクリープ評価について, 既往の研究を概説する.

綾野 2)は, W/C が 50〜65\%のコンクリートの変動応力 
下におけるクリープについて，重ね合せ理論と時間硬化 則およびひずみ硬化則による推定を行い，問題点を指摘 し,回復クリープを考慮した独自のクリープ硬化則を提 案している. 後藤ら ${ }^{3 /} /$ W/C が $45 〜 65 \%$ の範囲における 若材齢コンクリートの圧縮および引張クリープ試験を実 施している. また, 温度応力を模擬した応力パターンに おけるクリープ挙動を重ね合せ理論で推定した結果, 圧 縮除荷期間のクリープ回復量と圧縮クリープひずみ量の 関係を考慮することで，ひずみ挙動をよく評価できると している. 根木ら $\left.{ }^{4}\right)$ は, 若材齢時に生じるクリープがコ ンクリートの引張破壊に及ぼす影響について検討してい る. そのなかで, 応力強度比が $70 \%$ 以上では, 変形能 力は低下するとしている. また, 載荷材齢が大きくなっ ても変形能力は低下するとしている. 次に, マットモデ ルと壁モデルにおいて変動応力下のクリープ評価を行っ た．壁モデルのような急速温度降下型では，十分に重ね 合せ理論は適用可能であるが，マットモデルのような緩 速温度降下型で, 高応力強度比ではクリープは過少評価 されるとしている. 入矢ら ケタれタは圧縮および引張クリ 一プの室内試験を実施し, 各種要因がクリープに及ぼす 影響を検討している.そして，5要素レオロジーモデル を用いたクリープ関数を構築している. また，上記クリ 一プ関数を用いて, 単調応力作用時のクリープを重ね合 せ理論で推定できるとしている. 引張クリープについて は応力強度比・載荷材齢・養生および載荷温度の影響に ついて定式化し, 温度応力状態のクリープ試験結果と比 較している. 養生および載荷温度の影響について検討し， 高温ではクリープは大きくなるとしている. また, アレ ニウス式による材㱓と温度関数によって, クリープ式の 定式化を行っている. 次に, 応力単調増加パターンのク リープ試験を実施している. そして, 定式化したクリー プ式を用い, 重ね合せ理論によるクリープ推定結果と実 験結果との比較を行っている. また, 若材齢コンクリー トの回復ひずみのモデル化を行っている. さらに, 単調 除荷パターンのクリープ試験を実施し, 重ね合せ理論に より，除荷過程に回復ひずみモデルを用いた場合の推定 結果と実験結果との比較を行っている. その結果, 回復 ひずみモデルを用いた方が，実験值をよく評価するが，

圧縮クリープを用いた場合でも, 実用上は十分評価可能 であるとしている. Guénot ら ”は, 普通強度コンクリー トと高強度コンクリートを対象とし, 水和熱を考慮した 変動応力場のクリープの評価を行っている. 重ね合せ理 論により積算温度を考慮した粘弾性クリープ式を用いる ことにより, 変動応力下のクリープを評価できるとして いる. 以上, 現在までに若材龄コンクリートのクリープ に関して, 研究成果の蓄積は進みつつあるが, 変動応力 下における高強度コンクリートのクリープ推定について
検討されている例は少ないのが現状である．著者ら ${ }^{10}, 1112121$ ( 現在までに若材㱓高強度コンクリートのクリ 一プ評価方法の提案を目的として検討を行っている. 変 動応力下のクリープ評価について, 圧縮クリープ関数を 用い，重ね合せ理論による評価を行った。その結果，圧 縮応力の単調増加域では, 実測值とよく一致した。 しか し, 圧縮応力の除荷域および応力反転後の引張応力域に おいて推定值は実測值を大きく評価される結果となった. 一方で, 圧縮応力と圧縮応力の除荷および引張応力の載 荷に対するクリープを推定し, 重ね合せ理論により評価 すれば，実測值とよく一致するという報告がある ${ }^{3)}$. し かし, 先行圧縮応力の載荷履歷は, 除荷過程においても, そのまま続くとして仮定している.これは, 全載荷応力 除荷後も先行圧縮応力が作用し続けることを意味してお り, 合理的ではないと考えられる. そこで, 本研究では, 重㸚合せ理論の特に除荷過程における先行圧縮応力の取 り扱いについて, 圧縮応力の除荷ととらえ, 除荷応力の 大きさに応じて先行載荷応力を減じる手法を提案する.

\section{3. 重ね合せ理論によるクリープ推定法}

履歷理論による重ね合せ理論”は，コンクリートの温 度応力解析等でよく用いられてきた方法である. この方 法は載荷された応力を微小時間で分割して, 考慮する方 法である. 重ね合せ理論の特徴は, 一度作用された応力 が永久に作用し続ける点である．以下に重ね合せ理論に よるクリープ算定式を示す.

$$
\varepsilon_{c r}(t)=\sum_{j=0}^{t} \Delta \varepsilon_{j}(t-j)
$$

ここに,

$\varepsilon_{c r}(t):$ 材齢 $t$ 日におけるクリープひずみ $\Delta \varepsilon_{j}(t-j):$ 載荷時材齢 $j$ 日の応力増分に対寸る材 齢 $t$ 日におけるクリープひずみ

\section{4. 検討項目}

本研究では以下の項目について検討する.

(1) 修正重ね合せ理論の提案 (1)履歴応力低减法の提案

（2）若材齡高強度コンクリートのクリープ特性 (1)圧縮基本クリープ関数 (2)回復クリープとクリープ回復率

（3）変動応力下における修正重㸚合せ理論の汎用性の 検証

(1)高強度コンクリートを対象とした実験結果と推定 
結果の比較

(2)普通コンクリートでの適用性

以上の検討を行うため, 一定荷重載荷ならびに変動 荷重載荷のクリープ実験を実施した. また, 提案法の汎 用性を検証するため, 参考文献より実験值を引用して, ここで，提案する手法の汎用性を検証した.

\section{5. 修正重ね合せ理論の提案}

応力反転を含む変動応力下におけるクリープ推定法 として, 除荷過程以降において, 先行載荷応力(以下, 本論文では履歴応力という)を低減するとともに，除荷 に伴うクリープ推定に回復クリープを適用する方法を提 案する. 図-1 に本研究で提案する修正重ね合せ理論の 概要図を示す.

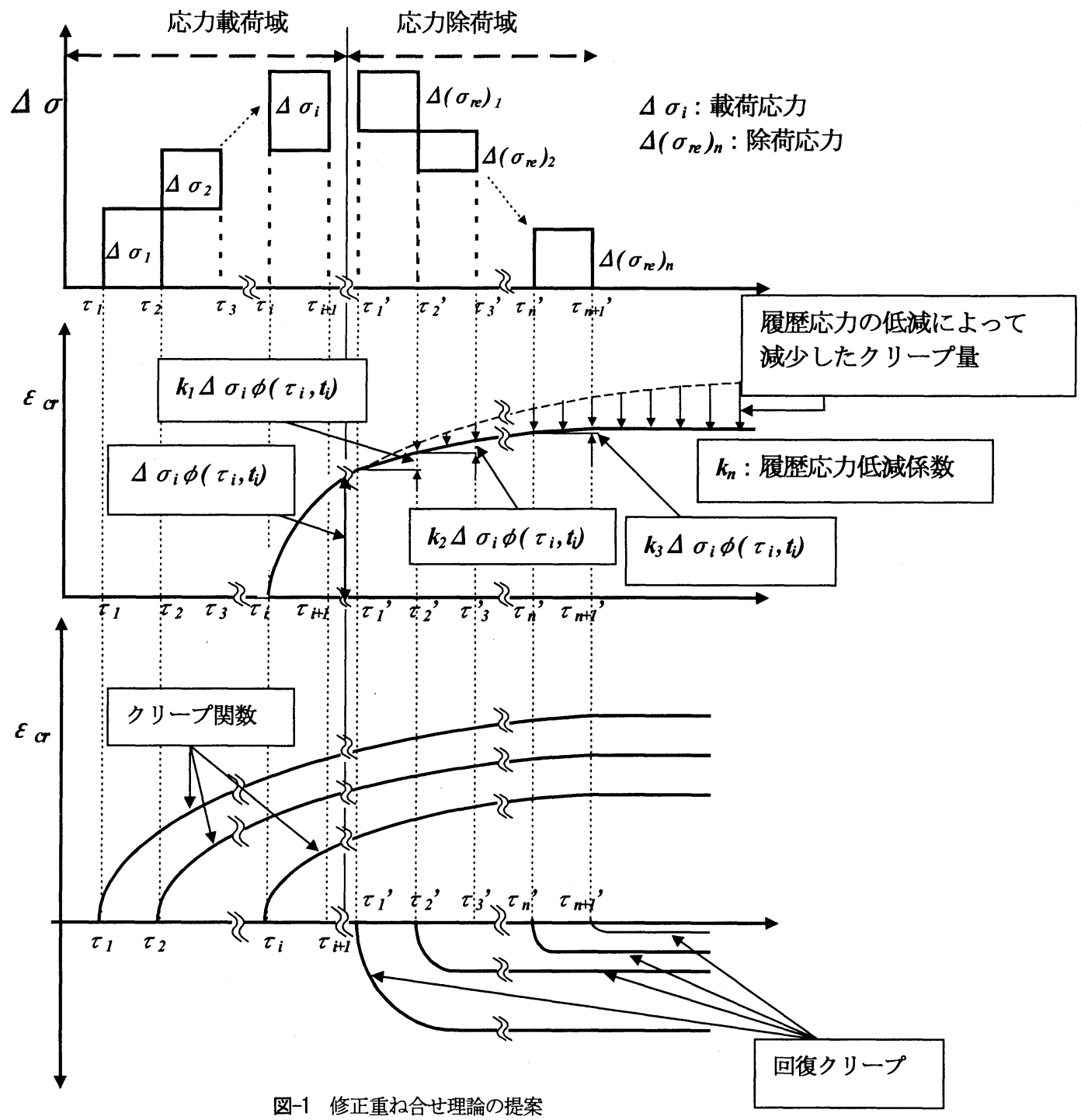


載荷期間 $\tau_{1} \sim \tau_{i+1}$ では, 従来の重ね合せ理論によるクリ 一プの推定を行う. まず, 載荷期間 $\tau_{1} \sim \tau_{i+1}$ で載荷され た応力 $\Delta \sigma_{1}$ から $\Delta \sigma_{i}$ に対するクリープひずみ $\varepsilon_{c r}\left(\tau_{i}, t_{i}\right)$ は式(2)で算定する. 次に, 除荷期間 $\tau_{1}^{\prime} \sim \tau_{n+1}^{\prime}$ では, 除 荷応力 $\left(\Delta \sigma_{r e}\right)_{n}$ を考慮して, 履歷応力低減係数 $k_{n}$ を載荷 応力 $\Delta \sigma_{1} \sim \Delta \sigma_{i}$ に乗じることで, 載荷期間 $\tau_{1} \sim \tau_{i+1}$ で 載荷した応力を低減させる. 本論文ではこの手法を履歷 応力低减法という。この方法は過去の先行載荷応力に応 じて, 除荷応力を按配し, 先行載荷応力を低减させる方 法である. $\Delta \sigma_{i}$ に対する履歷応力低减係数を式(3)に示 す. $k_{n}$ は各除荷域における除荷応力分を先行載荷応力 の合計で除したものを 1.0 から差し引くことにより, 除 荷による先行載荷応力の低減を表現したものである. $0.0 \leq k_{n} \leq 1.0$ の範囲で変化し, 1.0 の場合は, 先行載荷 応力がそのまま, 載荷され続けることを意味している. $k_{n}$ が小さくなることにより, 先行載荷応力が小さくな ることを示す. 除荷期間のクリープ量は式(4)により算

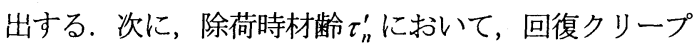
が発現するものとし, 回復クリープひずみ $\varepsilon_{r e}\left(\tau_{n}^{\prime}, t_{n}^{\prime}\right) を$ 式(5)で算出する. そして, 除荷期間におけるクリープ ひずみは, 式(6)に示すように, 式(4)のクリープ量を式 (5)の回復クリープひずみの和として算出する.

I. 載荷期間 : $\tau_{1} \sim \tau_{i+1}$ (従来の重ね合せ理論)

$$
\varepsilon_{c r}\left(\tau_{i}, t_{i}\right)=\sum_{i=1}^{i} \Delta \sigma_{i} \cdot \phi\left(\tau_{i}, t_{i}\right)
$$

II. 除荷期間 : $\tau_{1}^{\prime} \sim \tau_{n+1}^{\prime} \quad$ (履歴応力低減法 +

回復クリープ)

$\Delta \sigma_{i}$ に対する履歴応力低减係数 $k_{n}$ :

$$
\begin{gathered}
k_{n}=1.0-\frac{\left(\Delta \sigma_{r e}\right)_{1}+\left(\Delta \sigma_{r e}\right)_{2}+\cdot \cdot+\left(\Delta \sigma_{r e}\right)_{n}}{\Delta \sigma_{1}+\Delta \sigma_{2}+\cdot \cdot+\Delta \sigma_{i}}=1.0-\frac{\sum_{n=1}^{n}\left(\Delta \sigma_{r e}\right)_{n}}{\sum_{i=1}^{i} \Delta \sigma_{i}} \\
0.0 \leq k_{n} \leq 1.0 \quad(i=1,2,3 \cdots) \quad(n=1,2,3, \cdots) \\
\varepsilon_{c r}{ }^{\prime}\left(\tau_{n}^{\prime}, t_{n}^{\prime}\right)=k_{n} \cdot \Delta \sigma_{i} \cdot \phi\left(\tau_{i}, t_{i}\right)
\end{gathered}
$$

回復クリープに関する項目 :

$$
\varepsilon_{r e}\left(\tau_{n}^{\prime}, t_{n}^{\prime}\right)=\sum_{n=1}^{n}\left(\Delta \sigma_{r e}\right) \cdot \phi_{r e}\left(\tau_{o}, t, t_{n}^{\prime}\right)
$$

本研究の提案法

$$
\varepsilon_{c}=\sum_{i=1}^{i} \varepsilon_{c r}\left(\tau_{i}, t_{i}\right)+\sum_{n=1}^{n} \varepsilon_{c r}^{\prime}\left(\tau_{n}^{\prime}, t_{n}^{\prime}\right)+\sum_{n=1}^{n} \varepsilon_{r e}\left(\tau_{n}^{\prime}, t_{n}^{\prime}\right)
$$

ここに,

$\Delta \sigma_{i}$ : 載荷応力 $\left(\mathrm{N} / \mathrm{mm}^{2}\right), \quad\left(\Delta \sigma_{r e}\right)_{n}$ : 除荷応力 $\left(\mathrm{N} / \mathrm{mm}^{2}\right)$, $\tau_{i}$ : 載荷時材齢(日), $\tau_{n}^{\prime}$ : 除荷時材齢(日), $t_{i}$ : 載荷期 間(日), $t_{n}^{\prime}$ : 除荷期間(日), $\varepsilon_{c r}\left(\tau_{i}, t_{i}\right):$ 載荷時のクリープ ひずみ $\left(\times 10^{-6}\right), \varepsilon_{r e}\left(\tau_{n}^{\prime}, t_{n}^{\prime}\right):$ 回復クリープひずみ $\left(\times 10^{-6}\right)$, $\phi\left(\tau_{i}, t_{i}\right)$ : 単位クリープ関数 $\left(\times 10^{-6} \mathrm{~N} / \mathrm{mm}^{2}\right), \quad \phi_{r e}\left(\tau_{o}, t_{i}, t_{n}^{\prime}\right):$ 単位回復クリープ関数 $\left(\times 10^{-6} \mathrm{~N} / \mathrm{mm}^{2}\right), \tau_{o}$ : 初期載荷時材齢 (日), $\varepsilon_{c r}^{\prime}\left(\tau_{n}^{\prime}, t_{n}^{\prime}\right)$ :除荷期間のクリープひずみ $\left(\times 10^{-6}\right), \varepsilon_{c}:$ 全 クリープひずみ量 $\left(\times 10^{-6}\right), k_{n}$ : 履歴応力低減係数

\section{6. クリープ試験の概要}

\section{（1）供試体の作製}

図-2 に圧縮クリープ試験供試体と変動応カクリープ 試験供試体の形状・寸法を示す. 図に示すように, 供試 体の寸法は圧縮と回復および変動応カクリープ試験とも に, $100 \times 100 \times 200 \mathrm{~mm}$ とした. 変動応力クリープ用供試 体両端には, 4 本の異形鉄筋 $(\mathrm{D} 10 \times 80 \mathrm{~mm})$ で圧縮・引 張兼用の載荷板を取り付けた。 また, 材齢 1.5,3,7,14,28 日において圧縮強度,割裂引張強度および弾性係数を測 定した. クリープ供試体のひずみ計測には供試体断面中 央に配置した埋め込みひずみ計を用いた，各供試体は， 試験開始直前まで恒温恒湿室内（温度 $20^{\circ} \mathrm{C}$, 湿度 $60 \%$ 以上）で, 湿布養生を行った. 各クリープ供試体には試 験直前に，金属スプレーによる防水コートとアルミ䇴粘 着テープによる封縅処理を施した.本研究で用いた高強 度コンクリートの示方配合を表-1 に示す.セメントは普 通セメント(比表面積: $3360 \mathrm{~cm}^{2} / \mathrm{g}$, 密度 : $3.15 \mathrm{~g} / \mathrm{cm}^{3}$ )を用 いた.水セメント比は $30 \%$ とした.細骨材は長良川産砂 (密度 : $2.62 \mathrm{~g} / \mathrm{cm}^{3}$, FM:2.63) を用いた. 粗骨材は長良 川産砕石（密度 : $2.61 \mathrm{~g} / \mathrm{cm}^{3}$, 最大寸法 : $25 \mathrm{~mm}$ ）を用い た. 混和剤は高性能 $\mathrm{AE}$ 減水剤（ポリカルボン酸エーテ ル系と架橋ポリマーの複合体）を使用した強度および 弾性係数を表-2に示す.

\section{(2) クリープ試験装置}

本研究では図-3 に示すような油圧式の圧縮および引 張クリープ試験装置を用いた.圧縮および引張クリープ 試験機の最大容量は,それぞれ $500 \mathrm{kN}$ および $200 \mathrm{kN}$ であ る.ロードセルを用いて所定の荷重を供試体に載荷した 後,データロガーにより載荷後 2 時間毎に供試体のひず みと荷重とを計測した.試験期間中，クリープによる荷 重の減少量が,初期導入荷重の 3\%程度になった時点で, 荷重の再導入を行った. クリープ試験の測定ひずみには, 自己収縮ひずみ成分を含んでいるため, 同一の環境条件 下に置いた無載荷供試体に生じる自己収縮ひずみを測定 
し，クリープ試験の測定ひずみから差し引くことでクリ 一プひずみ成分を求めた.クリープ試験期間は, 供試体 のクリープ進行がほぼ定常状態となる材㱓 20 日までを 目安とした.

\section{（3）圧縮クリープ試験}

ここでは, 基本クリープ関数を推定するために, 圧 縮クリープ試験を行い，単位クリープを求める. 表-3 に試験ケースを示す，載荷時材㱓を $1.5,3,7,14$ および 28

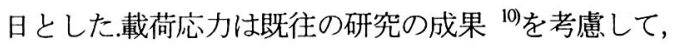
各材齢時の強度の $40 \%$ （以下, 載荷応力比とする）とし た. 載荷期間は 20 日とした. 試験の本数は各シリーズ 3本ずつとした。

\section{（4）回復クリープ試験}

ここでは，温度応力における除荷過程を検討するた めに, 応力載荷後の初期で, 除荷が起こった場合の回復 クリープ性状を把握することを目的とした．表-4 に試 験ケースを示寸．載荷時材齢は 1.5 日とした．載荷期間 は，打設初期の回復クリープ性状を把握するために， 1,3,5 日とし,コンクリートの性状がほぼ一定となる 27 日 を比較のために選定した．除荷期間は回復クリープがほ ぼ定常となる 6 日とした. 載荷応力比は $40 \%$ とした。 試験の本数は各シリーズ3本ずっとした。

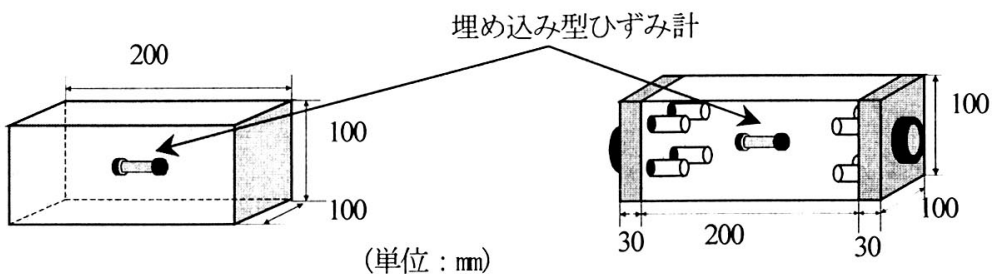

a) 圧縮・回復クリープ用

b) 変動応カクリープ用

図-2 供試体形状・寸法

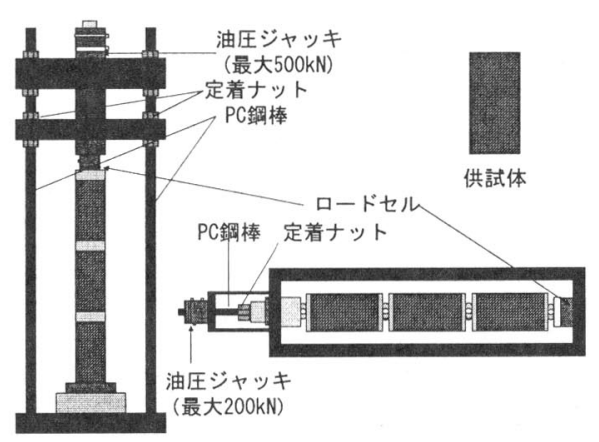

図-3 クリープ試験装置

表-1 示方配合
\begin{tabular}{|c|c|c|c|c|c|}
\hline \multirow{2}{*}{ W/C } & \multicolumn{5}{|c|}{ 単位量 $\left(\mathrm{kg} / \mathrm{m}^{3}\right)$} \\
\cline { 4 - 7 } & \multirow{2}{*}{$\mathrm{W}$} & $\mathrm{C}$ & $\mathrm{S}$ & $\mathrm{G}$ & $\mathrm{Ad}$ \\
\hline$\%$ & & & & & \\
\hline 30 & 132 & 440 & 840 & 1060 & 22 \\
\hline
\end{tabular}

*) 高性能 AE 減水剂

表-2 強度および弾性係数試験結果

\begin{tabular}{|c|c|c|c|}
\hline $\begin{array}{c}\text { 材撂令 } \\
(日)\end{array}$ & $\begin{array}{c}f c \\
\left(\mathrm{~N} / \mathrm{mm}^{2}\right)\end{array}$ & $\begin{array}{c}f t \\
\left(\mathrm{~N} / \mathrm{mm}^{2}\right)\end{array}$ & $\begin{array}{c}E c \\
\left(\times 10^{4} \mathrm{~N} / \mathrm{mm}^{2}\right)\end{array}$ \\
\hline 1.5 & 20.0 & 1.6 & 2.3 \\
\hline 3 & 60.0 & 4.4 & 3.3 \\
\hline 7 & 69.2 & 4.5 & 4.1 \\
\hline 14 & 78.7 & 5.6 & 4.0 \\
\hline 28 & 83.0 & 6.5 & 3.8 \\
\hline
\end{tabular}

表-3 圧縮クリープ供試体

\begin{tabular}{|c|c|c|c|}
\hline $\begin{array}{c}\text { 載荷時材齢 } \\
\text { (日) }\end{array}$ & $\begin{array}{c}\text { 載荷期間 } \\
\text { (日) }\end{array}$ & $\begin{array}{c}\text { 載荷応力比 } \\
(\%)\end{array}$ & $\begin{array}{c}\text { 本数 } \\
\text { (本) }\end{array}$ \\
\hline 1.5 & 20 & 40 & 3 \\
3 & 20 & 40 & 3 \\
7 & 20 & 40 & 3 \\
14 & 20 & 40 & 3 \\
28 & 20 & 40 & 3 \\
\hline
\end{tabular}

表-4 回復クリープ供試体

\begin{tabular}{|c|c|c|c|c|}
\hline $\begin{array}{c}\text { 載荷時材䀦 } \\
\text { (日) }\end{array}$ & $\begin{array}{c}\text { 載荷期間 } \\
(\text { 日) }\end{array}$ & $\begin{array}{c}\text { 載荷応力比 } \\
\text { (\%) }\end{array}$ & 本数 & $\begin{array}{c}\text { 除荷期間 } \\
\text { (日) }\end{array}$ \\
\hline 1.5 & 1 & 40 & 3 & 6 \\
1.5 & 3 & 40 & 3 & 6 \\
1.5 & 5 & 40 & 3 & 6 \\
1.5 & 27 & 40 & 3 & 6 \\
\hline
\end{tabular}




\section{7. 実験結果}

\section{（1）自己収縮ひずみの経時変化}

無載荷供試体に発生する自己収縮ひずみの経時変化の 一例を図-4 に示寸.図より，自己収縮ひずみは材齢のご く初期の段階から発生し, 材龄 5 日以降から增加速度は 小さくなるものの，長期にわたり進展することがわかる. 材歯 20 日における自己収縮ひずみは $200 \times 10^{-6}$ 程度であ った. この值を用いて, クリープひずみの補正を行った.

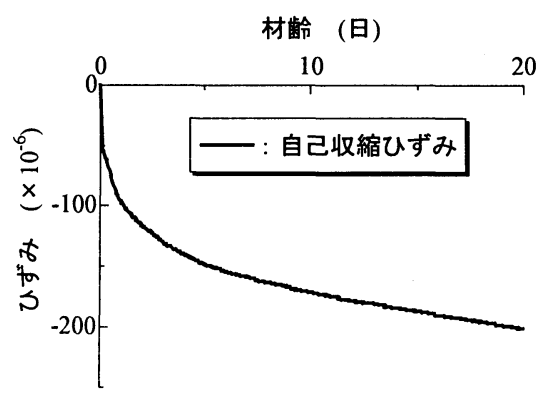

図-4 自己収縮ひずみの経時変化

載荷期間（日）

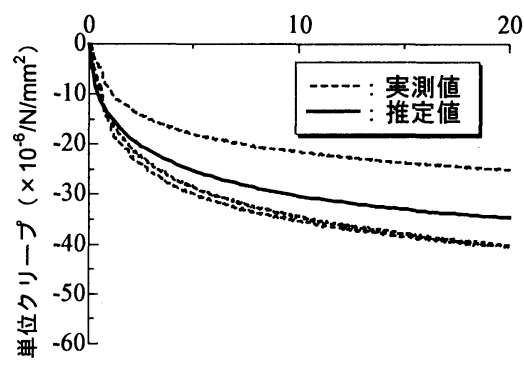

图-6 単位クリープ（載荷時材齢 3 日）

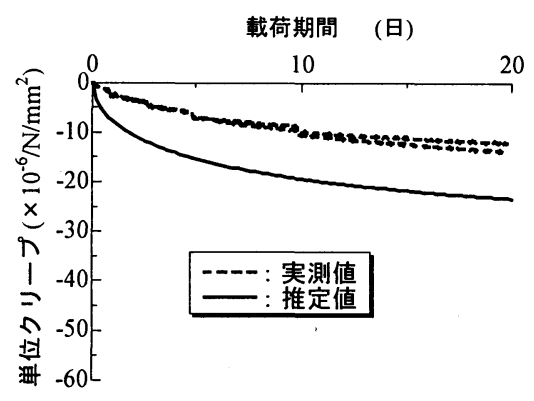

図-8 単位クリープ（載荷時材齢 14 日）

\section{（2）載荷時材齢の影響}

ここでは載荷応力比が $40 \%$ 以下で, 載荷時材齢が 1.5,3,7,14 および 28 日の各ケースにおける単位クリープ を図-5 9 に示寸. 図-10 に載荷時材歯 1.5 日の載荷期間 20 日におけるクリープ值を 1.0 とし, 各載荷時材龃の載 荷期間 20 日におけるクリープ值との比率を示す. 図よ り, 載荷時材歯 3 日で 0.65 程度まで減少し, その後の変 化は緩やかであることが分かる．以上より，載荷時材龄 1.5〜3 日にかけての材㱓初期に, クリープ特性が大きく 変化することことが確認できる.

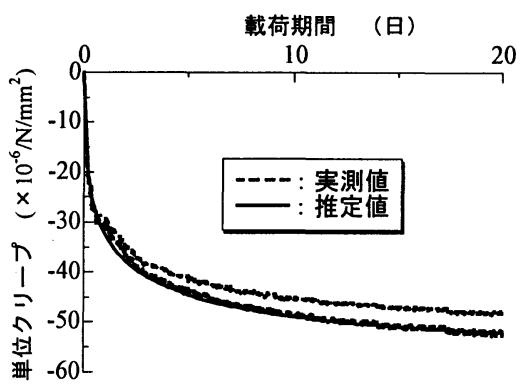

図-5 単位クリープ（載荷時材齢 1.5 日）

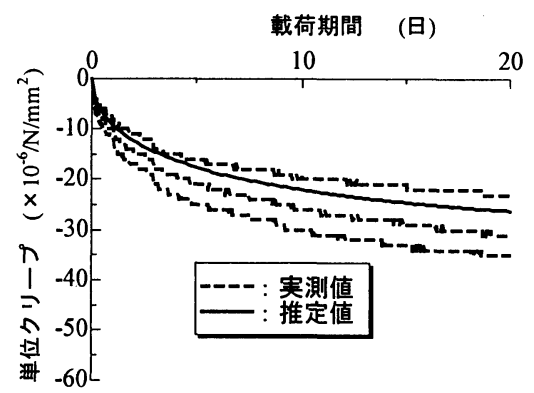

図-7 単位クリープ（載荷時材龄 7 日）

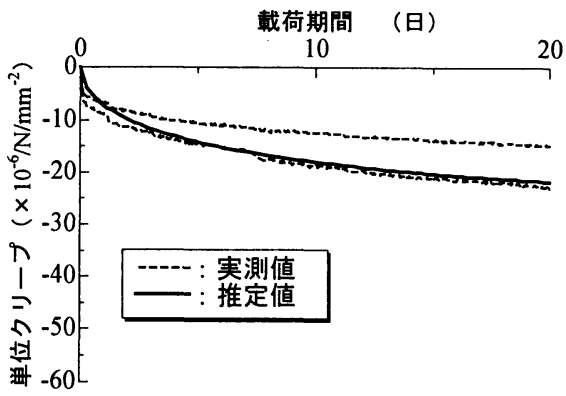

図-9 単位クリープ（載荷時材齢 28 日） 
（3）基本クリープ関数の推定

本研究では, 若材齢高強度コンクリートの基本クリ 一プ関数として,土木学会式 ${ }^{13)}$ を参考にして式(7)〜(11)の クリープ関数を用いることとした.本式は，載荷期間 20 日の終局クリープ值 $\gamma\left(\tau_{i}\right)$ にクリープ進行関数 $\beta\left(t_{i}\right)$ を乗 ずることで，単位応力あたりのクリープ值 $\phi\left(\tau_{i}, t_{i}\right)$ を評 価するものである.

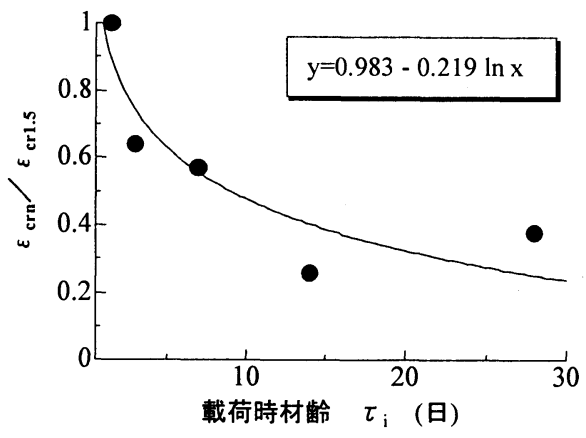

図-10 クリープ值の載荷時材齢の影響

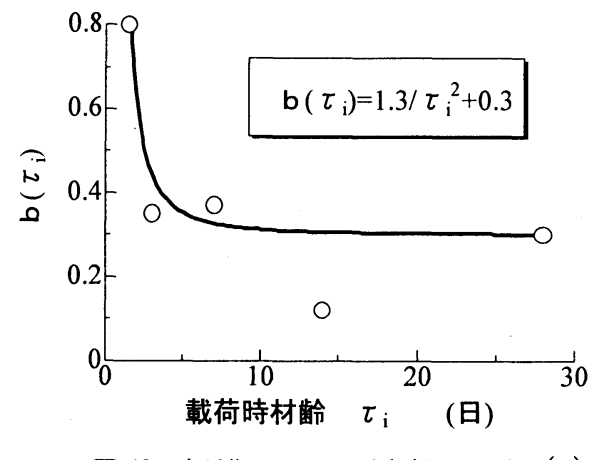

図-12 中長期のクリープ速度影響係数 $b\left(\tau_{\imath}\right)$

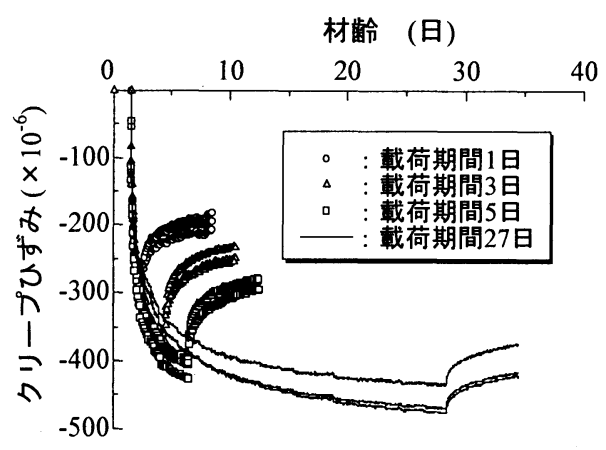

図-14 クリープひずみと回復クリープの経時変化

$$
\begin{aligned}
& \phi\left(\tau_{i}, t_{i}\right)=\gamma\left(\tau_{i}\right) \cdot \beta\left(t_{i}\right) \\
& \beta\left(t_{i}\right)=\left\{1-\exp \left(-b\left(\tau_{i}\right) \cdot t_{i}^{\wedge} c\left(\tau_{i}\right)\right)\right\} \\
& \gamma\left(\tau_{i}\right)=44 / \tau_{i}+26 \\
& b\left(\tau_{i}\right)=1.3 / \tau_{i}^{2}+0.3 \\
& c\left(\tau_{i}\right)=0.55 \cdot\left\{1-\exp \left(-0.9 \cdot \tau_{i}^{\wedge} 0.8\right)\right\}
\end{aligned}
$$

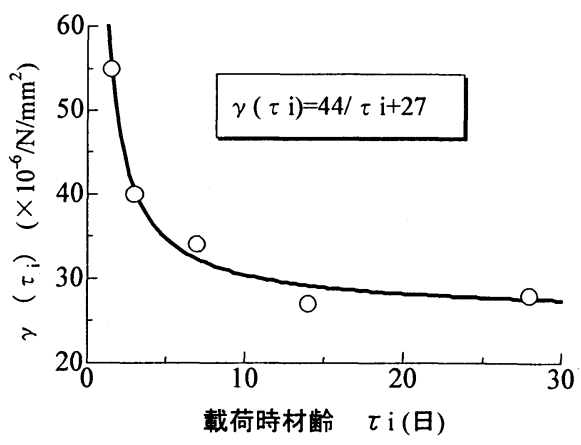

図-11 最終クリープ值 $\gamma\left(\tau_{i}\right)$

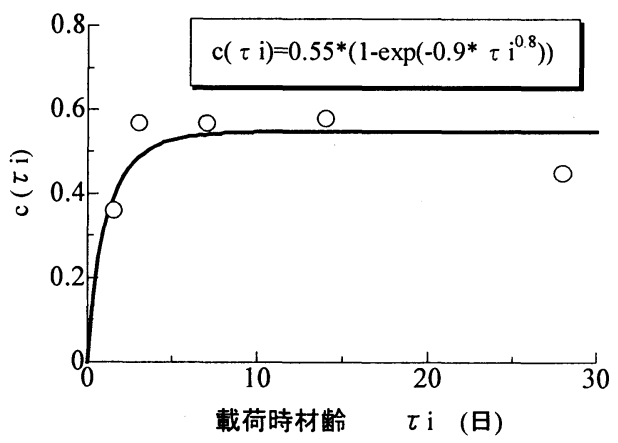

図-13 初期のクリープ速度影響係数 $c\left(\tau_{1}\right)$

載荷時材齢 1.5 日

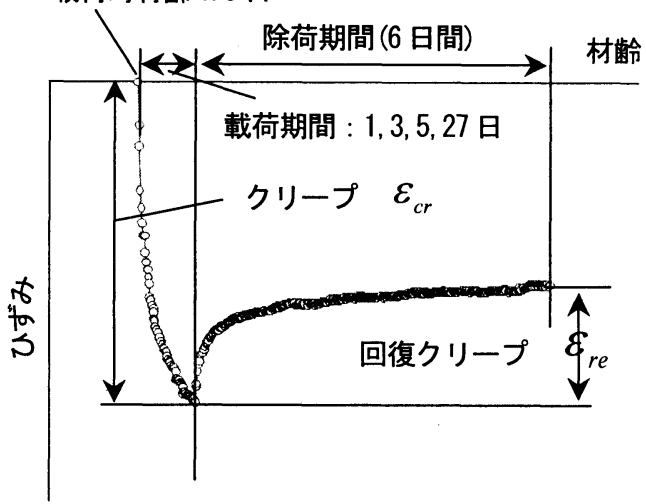

図-15 回復クリープ測定例 


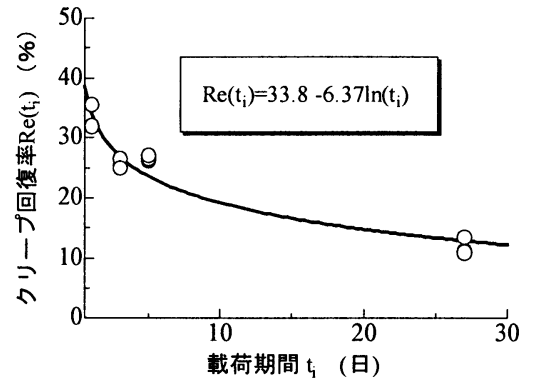

図-16 クリープ回復率

ここに, $\phi\left(\tau_{i}, t_{i}\right):$ 単位クリープひずみ $\left(\times 10^{-6} \mathrm{~N} / \mathrm{mm}^{2}\right)$, $\beta\left(t_{i}\right)$ : クリープ進行関数, $\chi\left(\tau_{i}\right)$ : 最終クリープひずみ $\left(\times 10^{6} \mathrm{~N} / \mathrm{mm}^{2}\right), t_{i}$ : 載荷期間（日）, $\tau_{i}:$ 載荷時材齢 (日), $b\left(\tau_{i}\right):$ 中長期のクリープ速度影響係数, $c\left(\tau_{i}\right):$ 初期 のクリープ速度影響係数

図-5〜9 に各材齢のクリープ試験結果を示寸。ここで は, 圧縮クリープ試験より得られた実験值の平均から最 小二乗法で近似関数を推定した. 係数 $b\left(\tau_{i}\right), c\left(\tau_{i}\right)$ はク リープ進行特性を表し, $b\left(\tau_{i}\right)$ が大きくなれば中・長期の クリープ速度が増大し, $c\left(\tau_{i}\right)$ が大きくなれば載荷初期の クリープ進行速度が増大する. $\gamma\left(\tau_{i}\right)$ および係数 $b\left(\tau_{i}\right), c\left(\tau_{i}\right)$ の值ならびにそれぞれの評価式を図-11 13 に示す. 図-11 より, 終局クリープ值 $\gamma\left(\tau_{i}\right)$ は, 材齢 1.5 日で $55 \times 10^{6} \mathrm{~N} / \mathrm{mm}^{2}$ を示すが，材齢の進行とともに，30 $\times 10^{6} \mathrm{~N} / \mathrm{mm}^{2}$ に漸近していくことがわかる. 図-12 に示 すように, 中長期のクリープ速度影響係数 $b\left(\tau_{i}\right)$ は, 材 齢 1.5 日の 0.8 から減少し，0.3 漸近することがわかる. 図-13 より, 初期のクリープ速度影響係数 $c\left(\tau_{i}\right)$ は, 材 齢 1.5 日で 0.35 程度であるが，材龄の進行とともの 0.5 程度に落ち着く傾向にある. 図-5 9 の推定値は式(7) 〜(11)の式を用いたものである. 載荷時材齢 14 日の推 定値は実測值を大きく評価している. しかし, 載荷時材 齢 1.5,3.7,28 日の推定值は, ほぼ実測値と一致している. 以上より,変動応力下のクリープ推定に際して, このク リープ関数を用いることとした. なお, 本研究では, 既 往の研究 ${ }^{2}$ 上りり圧縮クリープと引張クリープに大きな差 異がみられなかったことより, 圧縮クリープと引張クリ 一プの大きさは同じとして評価する.

\section{（4）回復クリープ試験結果}

図-14 に回復クリープ試験におけるクリープひずみと 回復クリープの経時変化を示す. 図は, 載荷期間 1,3,5,27 日の結果である. この試験結果をもとに, クリ ープ回復率を算出した. 図-15 にクリープ回復率の算出 方法を示す. 図に示すように, 載荷期間 $t_{i}=1,3,5,27$ 日 のクリープひずみ $\varepsilon_{c r}\left(t_{i}\right)$ を求め, 各除荷時材齢から除 荷期間 6 日間の回復クリープを求める. 回復クリープひ
ずみ $\varepsilon_{r e}\left(t_{i}\right)$ とクリープひずみ $\varepsilon_{c r}\left(t_{i}\right)$ の比を回復率 $R e\left(t_{i}\right)$ とする. 以下に算定式を示す.

$$
\operatorname{Re}\left(t_{i}\right)=\frac{\varepsilon_{r e}\left(t_{i}\right)}{\varepsilon_{c r}\left(t_{i}\right)}
$$

ここに, $t_{i}$ :載荷期間 1,3,5,27日, $R e\left(t_{i}\right):$ クリープ回復 率, $\varepsilon_{r e}\left(t_{i}\right)$ : 除荷期間 6 日間の回復クリープひずみ $\left(\times 10^{-}\right), \varepsilon_{c r}\left(t_{i}\right):$ 載荷期間 $t_{i}$ 日のクリープひずみ $\left(\times 10^{-6}\right)$

クリープ回復率の百分率と載荷期間との関係を図-16 に示す. 図より，載荷期間 1 日でクリープ回復率は，32 〜35\%となった. 載荷期間が 3,5 日ではクリープ回復率 は $25 \%$ 前後となった. コンクリートの物性がほぼ一定 と考えられる載荷期間 27 日では, クリープ回復率は

$12 \%$ 程度となった. 載荷期間が長くなると, クリープ回 復率は低下する傾向を示した. 若材齢期のクリープ回復 率については20～40\%程度とする報告がある8 ${ }^{8}$.

\section{（5）回復クリープ関数の推定}

初期載荷時材齢 $\tau_{o}$ のクリープ関数に回復率 $R \mathrm{e}\left(t_{i}\right)$ を かけることにより，回復クリープ関数を定義した.ここ では, 上記で得られた載荷時材齢 1.5 日の圧縮クリープ 関数にクリープ回復率を乗ずることで除荷時のクリープ 挙動を評価することとした．以下に単位回復クリープ関 数を示す.

$$
\begin{gathered}
\phi_{r e}\left(\tau_{o}, t_{i}, t_{n}^{\prime}\right)=\frac{\operatorname{Re}\left(t_{i}\right)}{100} \cdot \phi\left(\tau_{o}, t_{n}^{\prime}\right) \\
\operatorname{Re}\left(t_{i}\right)=33.8-6.37 \cdot \ln \left(t_{i}\right) \\
\left(t_{i} \geq 1.0\right) \\
\phi\left(\tau_{o}, t_{n}^{\prime}\right)=55.3 \cdot\left(1-\exp \left(-0.878 \cdot t_{n}^{\prime} \wedge 0.392\right)\right)
\end{gathered}
$$

ここに,

$\phi_{r e}\left(\tau_{o}, t_{i}, t_{n}^{\prime}\right):$ 単位回復クリープ $\left(\times 10^{-6} \mathrm{~N} / \mathrm{mm}^{2}\right), \operatorname{Re}\left(t_{i}\right):$ クリープ回復率 $(\%), \phi\left(\tau_{o}, t_{n}^{\prime}\right):$ 初期載荷時材齢 $\tau_{o}$ の単位 クリープ関数 $\left(\times 10^{6} \mathrm{~N} / \mathrm{mm}^{2}\right), t_{n}^{\prime}:$ 除荷期間(日) $\left(6.0 \leq t_{n}^{\prime}\right)$, $t_{i}$ : 載荷期間 $\left(\right.$ 日), $\tau_{o}:$ 初期載荷時材齢 $($ 日)ここでは, 1.5 日とする.

\section{8. 変動応力下における修正重ね合せ理論の汎用 性の検証}

\section{(1) はじめに}

本研究で提案した修正重ね合せ理論の汎用性を検証 するために, 変動応力下のクリープ試験結果と参考文献 より引用した実験データをもとに, クリープの推定を行 
った.

（2）変動応カ下のクリープ試験

図-17〜18に応力パターンを示す.これは，外部拘束 が卓越する場合の温度応力の発現パターンを模擬したも のである. なお, 導入応力は載荷材㱓時の強度の $40 \%$ 程 度とした. 図-17は応力除荷過程を検討するための応力

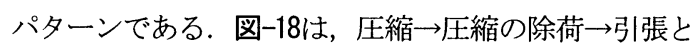
変化していくパターンである. 所定の応力変化材齢にお いて, 強度試験を行い, その強度試験結果の $40 \%$ 以内を 載荷応力とした. 試験の本数は各パターンでそれぞれ3 本ずつとした.

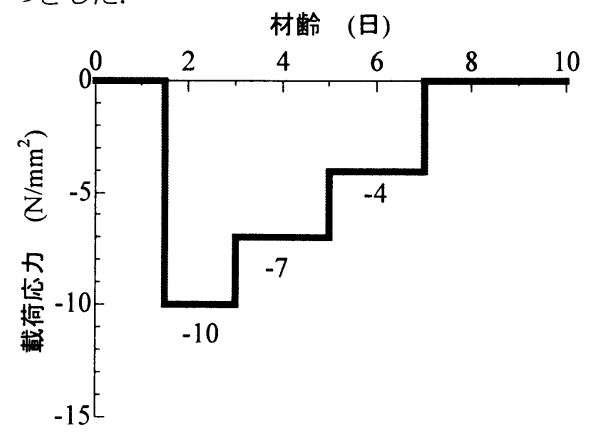

図-17 応力単調除荷パターン

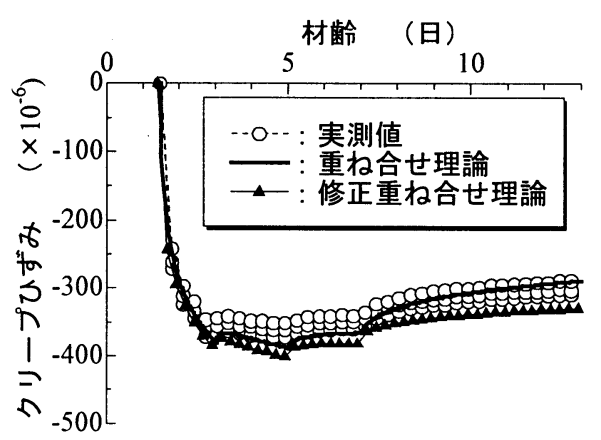

図-19＼cjkstart変動応力クリープ試験結果 (単調除荷型)



図-21 適用性の検証 $1\left(\right.$ 後藤ら $\left.{ }^{3}\right)$

\section{（3）実験結果と推定結果の比較}

a) 応力単調除荷型

図-17に示す単調除荷型の応力パターンによるクリー プ挙動を図-19に示す．まず，従来の履歴理論は，実測 值の範囲内で評価されているが，材蹂7日における3回目 の除荷以降，実測值よりも回復クリープを大きく評価す る傾向にある. 一方, 本研究の提案法は, 実測值よりも, 若干，回復クリープを小さく評価しているが，実測值の 傾向とよく一致していることが分かる.

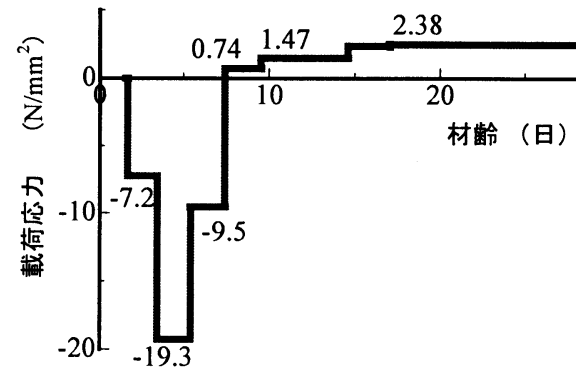

図-18 応力反転パターン

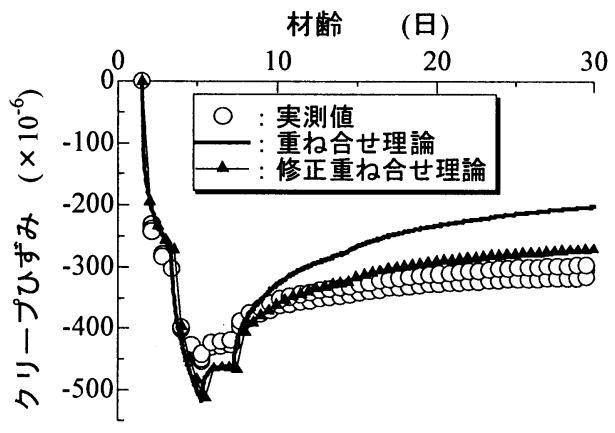

図-20 変動応カクリープ試験結果

(変動応力型)

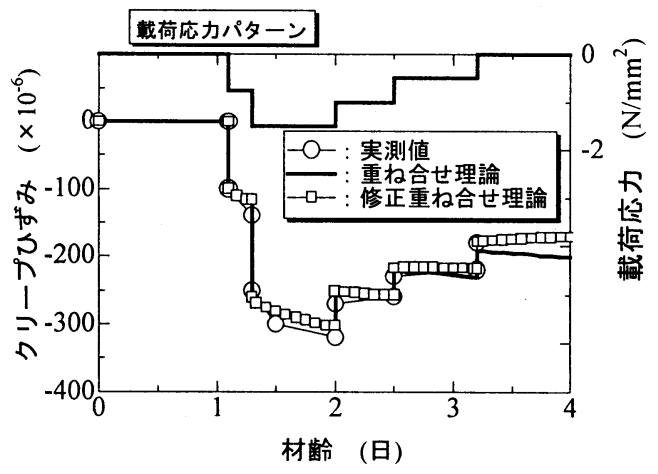

図-22 適用性の検証 2 (入矢ら ${ }^{8)}$ ) 


\section{b) 応力反転型}

図-18に示す温度応力を模擬した応力パターンによる クリープ挙動を図-20に示す，まず，従来の履歷理論に よる評価法は, 推定值が実測值を圧縮応力増加域および 圧縮応力除荷域において若干大きく評価しているが, 全 般的によく合致している. しかし, 応力が圧縮から引張 へ反転した後，実測值を大きく評価する傾向にある。一 方, 本研究の提案法による推定值は, 圧縮応力増加域と 圧縮応力除荷域も，実測值を若干大きく推定しているが， 全般によく一致している. また, 応力反転以降の引張応 力域において，推定值は実測值を大きく評価している. しかし, 重ね合せ理論に比へ，推定値と実測值の差は小 さいことが分かる. 以上のことから，本研究の提案法は， 応力反転以降のクリープ推定精度を向上させる一つの手 法としての有効性が示されたと考える.

\section{（4）普通コンクリートに対する修正重ね合せ理論の適 用性}

ここでは, 本提案法の適用性を検証するために, 参考 文献より引用した普通コンクリートに対する

変動応力下のクリープ試験結果と本提案法との推定結果 を比較した. 図-21に後藤ら 3 が実施した温度応力を模擬 した応力パターンにおけるクリープ試験の実測值および 修正重ね合せ理論によるクリープ推定結果を示す. 後藤 らは, W/C=55\%の普通コンクリートを対象として，圧 縮および引張クリープの構成式と圧縮の除荷クリープを 構筑し,重ね合せ理論により変動応力下のクリープ挙動 を推定している.ここでは，圧縮と引張および圧縮の除 荷クリープ構成式を用い, 除荷過程に履歴応力低减法を 用いた. 図より，推定値は圧縮応力域と圧縮の除荷域お よび引張応力域ともに, 実測值の挙動をよく捉えている ことが分かる. 次に, 図-22に入矢ら ${ }^{8}$ が実施した $\mathrm{W} / \mathrm{C}=55 \%$ で28日圧縮強度が $35 \mathrm{~N} / \mathrm{mm}^{2}$ の普通コンクリート を対象として，除荷過程のクリープ試験結果と本提案法 による推定結果を示す.ここでは, 土木学会コンクリー 卜標準示方書 ${ }^{13)}$ のクリープ推定式(圧縮強度 $55 \mathrm{~N} / \mathrm{mm}^{2}$ 以下) を用いた. 除荷過程の回復クリープは, クリープ回復率 を $30 \%$ とし ${ }^{8)}$ ，これを載荷時材歯1.1日のクリープ推定式 に乗ずることで求めた. 図より, 従来の重ね合せ理論に よる推定值は, 圧縮応力域で実測值をよく評価している. しかし, 圧縮応力除荷域において, 増加傾向を示してい る.これは, 圧縮応力域のクリープ值が除荷域にも影響 を及ぼしているためである. 一方，本提案法による推定 值は，除荷域においても実測值とよく合致していること がわかる. 以上より，本提案法の適用性が検証できたと 考えられる.

\section{9. まとめ}

本研究では, 変動応力下のクリープ推定法について検 討した. 以下に得られた知見をまとめる.

(1) 応力反転を含む変動応力下におけるクリープ推定法 として, 除荷過程以降において, 履歴応力を低減す るとともに，除荷に伴うクリープ推定に回復クリー プを適用する修正重ね合せ理論を提案した。

(2) 回復クリープは, 基本クリープ関数にクリープ回復 率を乗じることにより，評価することが可能である.

（3）若材龄コンクリートのクリープ回復率は, 載荷期間 1日で32〜35\%程度となり，3,5日ではクリープ回復 率は25\%前後となった. コンクリートの物性がほぼ 一定と考えられる載荷期間27日では, クリープ回復 率は $12 \%$ 程度となった. 載荷期間が長くなると, ク リープ回復率は低下寸る傾向を示した。

（4）参考文献より引用した普通コンクリートのクリープ 試験結果と本研究で提案した修正重ね合せ理論によ る推定值はよく一致した. このことより, 本提案法 は，十分なる適用性を有すると考える。

\section{参考文献}

1) McHenry,D : A New aspect of creep in concrete and its application to design,Proc.A.S.T.M.40, pp.1069-1084,1943.

2) 綾野克紀 : コンクリートの乾燥収縮およびクリープの予測 とその設計一の適用に関する研究,岡山大学学位論文,1993.3.

3）後藤忠広, 上原匠, 梅原秀哲: 若材龄コンクリートのクリ 一プ挙動に関する研究, コンクリート工学年次論 文報告 集, Vol.17, No.1, pp.1133-1138,1995.

4) 根木崇文, 入矢桂史郎, 梅原秀哲 : 若材龄のクリープがコ ンクリートの引張破壊に与える影響に関する検討，コンク リート工学年次論文報告集, Vol.21, No.2, pp.757-762, 1999.

5）入矢桂史郎, 平本昌生, 服部達也, 梅原秀哲 : 若材齢コン クリートの圧縮クリープに関する研究, 土木学会論文 集,No.599/V-40,pp.1-14,1998.8.

6) 入矢桂史郎, 根木崇文, 服部達也, 梅原秀哲 : 若材龄コン クリートの引張クリープに関する研究, 土木学会論文 集,No.620/V-43,pp.201-213,1999.5.

7) 入矢桂史郎, 服部達也, 梅原秀哲: 若材齢コンクリートの 圧縮クリープと引張クリープの比較に関する研究、土木学 会論文集,No.599/N-40,pp.105-117,1998.8.

8）入矢桂史郎,服部達也,根木崇文,梅原秀哲 : 若材齢コンクリー トの除荷過程におけるクリープ挙動のモデル化に関する研 究,士木学会論文集,No.613/V-42,pp.164-174,1999.2.

9) Guenot,I, Torrenti,JM, and Laplante,P : Stress in Concrete at earty ages: Comparison of Different Creep Models, Thermal Cracking in Concrete at Earty Ages. Edited by RSpringenschmid, Published 1994,by E\&FN 
Spon,2-6,Boundary Row, London SE1,8HN,UK.ISBN:0419.

10) Ozawa, $\mathrm{M}$ and Morimoto, $\mathrm{H}$ : Evaluation of Creep of High-strength concrete at early ages, Control cracking in Earty Age Concrete, Mihashi\& Wittmann (eds), pp.255-264, 2002.

11) 小澤満津雄, 森本博昭 : 若材齢高強度コンクリートのクリ 一プ推定法, pp.259-266, 日本コンクリート工学協会, コ ンクリート構造物のクリープおよび収縮による時間依存変 形に関するシンポジウム, 2001 .

12) 小澤満津雄, 森本博昭,国森亮平,車戸勝巳 : 若材齢高強度コ ンクリートのクリープ特性に関する基礎的研究,コンクリ 一ト工学年次講演論文集,Vol.22,NO.2,631-636,2000.
13) 土木学会 : コンクリート標準示方書, [構造性能照査編], 2002

(2003. 3. 26 受付)

\title{
EVALUATION OF CREEP IN HIGH-STRENGTH CONCRETE UNDER CHANGING STRESS AT EARLY AGES
}

\author{
Mitsuo OZAWA, Yohsuke HOSOI and Hiroaki MORIMOTO
}

\begin{abstract}
In this study, we proposed a method for creep evaluation in high-strength concrete under changing stress at early ages. We used creep recovery ratio obtained from creep tests for estimation of creep behavior accompanying with stress unloading, beside decreased values of precedent sustained stress to consider the stress unloading in applying super position method. Application of the method was examined through a few examples of calculation.
\end{abstract}

